\title{
Personality Rights in European Tort Law
}

This volume provides a comprehensive analysis of civil liability for invasion of personality interests in Europe. It is the final product of the collaboration of twenty-seven scholars and includes case studies of fourteen European jurisdictions, as well as an introductory chapter written from a US perspective. The case studies focus in particular on the legal protection of honour and reputation, privacy, self-determination and image. This volume aims to detect hidden similarities (the 'common core') in the actual legal treatment accorded by different European countries to personal interests which in some of these countries qualify as 'personality rights', and also to detect hidden disparities in the 'law in action' of countries whose 'law in the books' seem to protect one and the same personality interest in same way.

GERT BRÜGGemeIER is Professor (Emeritus) of Civil Law, European Economic Law and Comparative Law at the University of Bremen.

aurelia colombi ciacchi is Senior Researcher in Private Law at the University of Bremen and Lecturer at the Hanse Law School, Bremen.

PATRICK O'CALLAGHAN is Lecturer in Law at Newcastle University. 
Cambridge University Press

978-0-521-19491-4 - Personality Rights in European Tort Law

Edited by Gert Brüggemeier , Aurelia Colombi Ciacchi , Patrick O'Callaghan

Frontmatter

More Information

THE COMMON CORE OF EUROPEAN PRIVATE LAW

\section{General Editors}

Mauro Bussani, University of Trieste

Ugo Mattei, University of Turin and University of California, Hastings College of Law

\section{Honorary Editor}

Rodolfo Sacco, University of Turin

\section{Editorial Board}

James Gordley, W. R. Irby Chair in Law, Tulane University Law School

Antonio Gambaro, Professor of Law, University of Milano; President of the Italian

Society of Comparative Law

Franz Werro, University of Freiburg and Georgetown University Law Center

Rodolfo Sacco, President of the International Association of Legal Science (UNESCO)

For the transnational lawyer the present European situation is equivalent to that of a traveller compelled to cross legal Europe using a number of different local maps. To assist lawyers in the journey beyond their own locality The Common Core of European Private Law Project was launched in 1993 at the University of Trento under the auspices of the late Professor Rudolf B. Schlesinger.

The aim of this collective scholarly enterprise is to unearth what is already common to the legal systems of European Union Member States. Case studies widely circulated and discussed between lawyers of different traditions are employed to draw at least the main lines of a reliable map of the law of Europe.

Books in the series

Personality Rights in European Tort Law edited by Gert Brüggemeier, Aurelia Colombi Ciacchi and Patrick O’Callaghan 9780521194914

Precontractual Liability

edited by John Cartwright and Martijn Hesselink

9780521516013

Environmental Liability and Ecological Damage in European Law edited by Monika Hinteregger 9780521889971 Hardback

The Enforcement of Competition Law in Europe edited by Thomas M. J. Möllers and Andreas Heinemann 9780521881104 Hardback

Commercial Trusts in European Private Law edited by Michele Graziadei, Ugo Mattei and Lionel Smith 9780521849197 
Cambridge University Press

978-0-521-19491-4 - Personality Rights in European Tort Law

Edited by Gert Brüggemeier , Aurelia Colombi Ciacchi , Patrick O'Callaghan

Frontmatter

More Information

Mistake, Fraud and Duties to Inform in European Contract Law edited by Ruth Sefton-Green

0521844231 Hardback

Security Rights in Movable Property in European Private Law edited by Eva-Maria Kieninger

052183967 X Hardback

Pure Economic Loss in Europe

edited by Mauro Bussani and Vernon Valentine Palmer

0521824648 Hardback

The Enforceability of Promises in European Contract Law edited by James Gordley

0521790212 Hardback

Good Faith in European Contract Law

edited by Reinhard Zimmermann and Simon Whittaker

0521771900 Hardback 


\section{CAMBRIDGE}

Cambridge University Press

978-0-521-19491-4 - Personality Rights in European Tort Law

Edited by Gert Brüggemeier, Aurelia Colombi Ciacchi , Patrick O'Callaghan

Frontmatter

More Information

\section{Personality Rights in European Tort Law}

Edited by

Gert Brüggemeier, Aurelia Colombi Ciacchi and Patrick O'Callaghan 
Cambridge University Press

978-0-521-19491-4 - Personality Rights in European Tort Law

Edited by Gert Brüggemeier , Aurelia Colombi Ciacchi , Patrick O'Callaghan

Frontmatter

More Information

\section{CAMBRIDGE}

UNIVERSITY PRESS

University Printing House, Cambridge CB2 8BS, United Kingdom

One Liberty Plaza, 20th Floor, New York, NY 10006, USA

477 Williamstown Road, Port Melbourne, VIC 3207, Australia

314-321, 3rd Floor, Plot 3, Splendor Forum, Jasola District Centre, New Delhi - 110025, India

103 Penang Road, \#05-06/07, Visioncrest Commercial, Singapore 238467

Cambridge University Press is part of the University of Cambridge.

It furthers the University's mission by disseminating knowledge in the pursuit of education, learning and research at the highest international levels of excellence.

www.cambridge.org

Information on this title: www.cambridge.org/9780521194914

(C) Cambridge University Press 2010

This publication is in copyright. Subject to statutory exception and to the provisions of relevant collective licensing agreements, no reproduction of any part may take place without the written permission of Cambridge University Press.

First published 2010

A catalogue record for this publication is available from the British Library

Library of Congress Cataloging in Publication data

Personality rights in European tort law / [edited by] Gert Brüggemeier, Aurelia

Colombi Ciacchi and Patrick O'Callaghan.

p. $\mathrm{cm}$.

Includes index.

ISBN 978-0-521-19491-4 (hardback)

1. Personality (Law)-Europe. 2. Privacy, Right of-Europe. 3. Torts-

Europe. 4. Personality (Law)-United States. 5. Privacy, Right of-United

States. 6. Torts-United States. I. Brüggemeier, Gert, 1944- II. Ciacchi, Aurelia

Colombi III. O’Callaghan, Patrick.

KJC1646.P47 2010

346.2403'3-dc22 2009052177

ISBN 978-0-521-19491-4 Hardback

Cambridge University Press has no responsibility for the persistence or accuracy of URLs for external or third-party internet websites referred to in this publication, and does not guarantee that any content on such websites is, or will remain, accurate or appropriate. 


\section{Contents}

List of contributors

\section{Part I Mapping the legal landscape}

1 General introduction

2 Protection of personality rights in the law of delict/torts in Europe: mapping out paradigms

GERT BRÜGGEMEIER

1 Introduction

2 Two distinct paths of civil law of delict

A France

B Germany

3 Two different paths of liability law

A Common law of torts and statutory law: England

B Scandinavian law: Sweden

4 A European perspective - Art. 8(1) ECHR 30

3 American tort law and the right to privacy 38

JOSEPH A. PAGE

1 Introduction

2 The birth of a tort

3 The first steps 
Cambridge University Press

978-0-521-19491-4 - Personality Rights in European Tort Law

Edited by Gert Brüggemeier, Aurelia Colombi Ciacchi , Patrick O'Callaghan

Frontmatter

More Information

viii

CONTENTS

4 Evolution of a tort

5 Additional protection for peace of mind

6 The academic backlash

7 The United States Supreme Court intervenes

8 The present status of the unwarranted-disclosure privacy tort

9 The present status of the intrusion privacy tort

10 The present status of the false-light privacy tort

11 The present status of the misappropriation privacy tort

12 Conclusion

Part II Case studies

4 Case 1: The corrupt politician 75

Case $\quad 75$

Discussions $\quad 75$

Comparative remarks 140

5 Case 2: Convicted law professor $\quad 149$

Case 149

Discussions 149

Comparative remarks 175

6 Case 3: The paedophile case 178

Case 178

Discussions 178

Comparative remarks 203

7 Case 4: An invented life story? 206

Case 206

Discussions 206

Comparative remarks 225

8 Case 5: A former statesman's family life 228

Case 228

Discussions 228

Comparative remarks 253 


\section{CAMBRIDGE}

Cambridge University Press

978-0-521-19491-4 - Personality Rights in European Tort Law

Edited by Gert Brüggemeier , Aurelia Colombi Ciacchi , Patrick O'Callaghan

Frontmatter

More Information

9 Case 6: A satirical magazine

Case

Discussions

257

Comparative remarks

10 Case 7: A snapshot of a person

Case

Discussions

Comparative remarks

11 Case 8: A paparazzo's telephoto lens

Case

Discussions

Comparative remarks

12 Case 9: Naked.Little.Girl.Com 348

Case

Discussions

Comparative remarks

13 Case 10: The late famous tennis player

Case

Discussions

375

Comparative remarks

14 Case 11: The popular TV presenter

Case

Discussions

Comparative remarks

15 Case 12: Copied emails

Case

Discussions

Comparative remarks

16 Case 13: Brigitte's diaries

Case

Discussions

Comparative remarks 
Cambridge University Press

978-0-521-19491-4 - Personality Rights in European Tort Law

Edited by Gert Brüggemeier , Aurelia Colombi Ciacchi , Patrick O'Callaghan

Frontmatter

More Information

17 Case 14: Tape recordings of a committee meeting

Case

Discussions

Comparative remarks

18 Case 15: 'Light cigarettes reduce the risk of cancer'

492

Case

492

Discussions

492

Comparative remarks

19 Case 16: Doctor's non-disclosure of a foetal disease

Case

Discussions

511

Comparative remarks

20 Case 17: WAF - A gang of incompetents?

Case

Discussions

Comparative remarks

\section{Part III A common core of personality protection}

21 A common core of personality protection

GERT BRÜGGEMEIER, AURELIA COLOMBI CIACCHI

AND PATRICK O'CALLAGHAN

1 Dignity and honour

2 Privacy

3 Right to one's image and likeness

4 Commercial appropriation of personality

5 Right to personal identity

6 Self-determination

7 Protection of personality of legal persons?

8 Personality violations through the internet

9 Conclusion 


\section{Contributors}

JOHAN BÄRLUnd, LLD, MSC, Professor of Civil and Commercial Law, University of Helsinki, Finland

GERT BRÜGgemeIER, DR IUR., Professor (Emeritus) of Civil Law, European Economic Law and Comparative Law, University of Bremen, Germany VAL CORBETT, BCL, LLM, Head of Law School, Independent College Dublin, Ireland

AURELIA COLOMBi CIACCHI, DR IUR., Dottore di ricerca, LLM, Senior Researcher in Private Law, University of Bremen, Germany, and Lecturer, Hanse Law School, Bremen, Germany

NUNO FERREIRA, DR IUR., Lecturer in Law, University of Manchester, United Kingdom

CARlos Gómez-ligüerre, Dr iUR., Professor of Private Law, Universitat Pompeu Fabra, Barcelona, Spain

AXEL HAlFMEIER, DR IUR., Professor of Private and Economic Law, Frankfurt School of Finance \& Management, Frankfurt am Main, Germany

Ute hammerschall, Magistrate, Barrister, (formerly) Researcher in Law, University of Graz, Austria

GERAINT HOWELls, LLb, Barrister, Professor of Commercial Law, University of Manchester, United Kingdom

AGNÈS LUCAS-SCHLÖTTER, DR IUR., Lecturer in French Legal Terminology, Ludwig-Maximilians University of Munich, Germany

PATRICK O'CALLAGHAN, DR IUR., Lecturer in Law, Newcastle University, United Kingdom 


\section{CAMBRIDGE}

Cambridge University Press

978-0-521-19491-4 - Personality Rights in European Tort Law

Edited by Gert Brüggemeier , Aurelia Colombi Ciacchi , Patrick O'Callaghan

Frontmatter

More Information

xii

LIST OF CONTRIBUTORS

JOSEPH A. PAGE, PHD, BA, LLB, LLM, Professor of Law, Director of the Center for the Advancement of the Rule of Law in the Americas, Georgetown Law School, Washington DC USA

PEDRO PAIS DE VASCONCELOS, DR IUR., Professor of Private Law, University of Lisbon, Portugal

KARL-NikOlaUS PEIFER, DR IUR., Professor of Civil Law, Intellectual Property Law and Economic Law, University of Cologne, Germany

Giorgio Resta, Dottore Di RiCerCA, Associate Professor of Private Comparative Law, University of Bari, Italy

PANAGIOTIS RIgopoulos, DR IUR., lawyer at the European Patent Office, Munich, Germany

PETER ROTT, DR IUR., Junior Professor of Private Law with a focus on European Private Law, University of Bremen, Germany

JUAN ANTONIO RUIZ GARCIA, DR IUR., Barrister, Researcher in Law, Universitat Pompeu Fabra, Barcelona, Spain

BERND SCHILCHER, DR IUR., Professor (Emeritus) of Private Law, Foreign and International Private Law, University of Graz, Austria

Peter SCHWARZENegger, DR IUR., Assistant Professor of Private Law, Foreign and International Private Law, University of Graz, Austria

CARla H. SIEbURGh, DR IUR., Professor of Private Law, University of Nijmegen, The Netherlands

LESLEY JANE SMITH, DR IUR., Professor of International and European Economic Law, University of Lüneburg, Germany

SYLVIA STAVRIDOU, DR IUR., Lecturer in Private Law, Democritus University of Thrace, Greece

FREDERIK SWENNEN, DR IUR., Professor of Persons and Family Law, University of Antwerp, Belgium

ALEXANDER WARZILEK, Magistrate, Lawyer, (formerly) Researcher in Law, University of Graz, Austria

FRANZ WERRO, DR IUR., LLM, Professor of Law of Obligations and European

Private Law, University of Fribourg, Switzerland, and Professor of Law, Georgetown Law School, Washington DC, USA

BRITT WEYTS, DR IUR., Professor of Civil Law, University of Antwerp, Belgium 
Cambridge University Press

978-0-521-19491-4 - Personality Rights in European Tort Law

Edited by Gert Brüggemeier , Aurelia Colombi Ciacchi , Patrick O'Callaghan

Frontmatter

More Information

\section{National reporters}

$\begin{array}{ll}\text { AUSTRIA: } & \text { Ute Hammerschall, Bernd Schilcher, Peter } \\ & \text { Schwarzenegger and Alexander Warzilek } \\ \text { BELGIUM: } & \text { Frederik Swennen and Britt Weyts } \\ \text { ENGLAND: } & \text { Geraint Howells and Peter Rott } \\ \text { FRANCE: } & \text { Agnès Lucas-Schlötter } \\ \text { FINLAND: } & \text { Johan Bärlund } \\ \text { GERMANY: } & \text { Axel Halfmeier and Karl-Nikolaus Peifer } \\ \text { GREECE: } & \text { Panagiotis Rigopoulos and Sylvia Stavridou } \\ \text { IRELAND: } & \text { Val Corbett } \\ \text { ITALY: } & \text { Aurelia Colombi Ciacchi (Cases 1, 2, 3, 4, 6, 15, } \\ & \text { 16, 17) and Giorgio Resta (Cases 5, 7, 8, 9, 10, 11, } \\ & \text { 12, 13, 14) } \\ \text { NETHERLANDS: } & \text { Carla Sieburgh } \\ \text { PORTUGAL: } & \text { Nuno Ferreira and Pedro Pais de Vasconcelos } \\ \text { SCOTLAND: } & \text { Lesley Jane Smith } \\ \text { SPAIN: } & \text { Juan Antonio Ruiz Garcia and Carlos Ignacio } \\ & \text { Gomez Liguerre } \\ \text { SWITZERLAND: } & \text { Franz Werro }\end{array}$




\section{General editors' preface}

This is the twelfth book in the series The Common Core of European Private Law published within the Cambridge Studies in International and Comparative Law. The project was launched in 1993 under the auspices of the late Professor Rudolf B. Schlesinger.

The methodology used in the project is still unparalleled. By making use of case studies it goes beyond mere description to detailed inquiry into how most European Union legal systems resolve specific legal questions in practice, and to thorough comparison between those systems. It is our hope that these volumes will provide scholars with a valuable tool for research in comparative law and in their own national legal systems. The collection of materials that the Common Core Project is offering to the scholarly community is already quite extensive and will become even more so when more volumes are published. The availability of materials attempting a genuine analysis of how things are is, in our opinion, a prerequisite for a fully-fledged and critical discussion on how they should be. Perhaps in the future European private law will be authoritatively restated or even codified. The analytical work carried on today by the almost 200 scholars involved in the Common Core Project is a precious asset of knowledge and legitimisation for any such normative enterprise.

We must thank the editors and contributors to the already published volumes, and those who are working hard to achieve future results. With a sense of deep gratitude we also wish to recall our late Honorary Editor, Professor Rudolf B. Schlesinger. We are sad that we have not been able to present him with the scholarly outputs of a project in which he believed so firmly.

No scholarly project can survive without committed sponsors. The Italian Ministry of Scientific Research is funding the project, having 
recognised it as a 'research of national interest'. The International University College of Turin with the Compagnia di San Paolo and the Consiglio Nazionale del Notariato allow us to organise the General Meetings. The European Commission has partially sponsored some of our past general meetings, having included them in their High Level Conferences Programme. The University of Torino, the University of Trieste, the Fromm Chair in International and Comparative Law at the University of California and the Hastings College of Law, the Centro Studi di Diritto Comparato of Trieste, have all contributed to the funding, and/or the success of this project.

Our home webpage is at www.iuctorino.it. There you can follow our progress in mapping the common core of European private law.

\section{General Editors}

MAURO BUSSANI (University of Trieste)

UGO MATTEI (University of Turin and University of California, Hastings College of Law)

\section{Honorary Editor}

RUDOLFO SACCO (University of Turin)

\section{Late Honorary Editor}

RUDOLF B. SCHLESINGER (Cornell University - University of California, Hastings) 


\section{Preface}

Comparative legal studies performed by a large network of academics from many different countries usually require many years of work and indeed a great deal of patience from all persons involved. This book, like most volumes of the Common Core series, is no exception to this rule. A first draft questionnaire on civil liability for the violation of personality rights was presented by Gert Brüggemeier and Aurelia Colombi Ciacchi and discussed in Trento in 2001. After settling on the final version of the questionnaire, first draft country reports were completed between 2002 and 2004. In August 2004, Patrick O'Callaghan joined the editors' team. Draft comparative remarks and an introductory chapter were written in 2005-06. Then the last missing country reports were drafted and the review of the other reports and the drawing of our conclusions for this project continued until early 2007, followed by final editing and proofreading until 2008.

We would like to express our deepest thanks to all national reporters and contributors for their enthusiasm and long-term commitment to this project, which did not provide any other remuneration but for the publication itself and the enjoyment of wonderful meetings in both Trento and Turin.

We are grateful to the general editors of the Common Core project, Mauro Bussani and Ugo Mattei, for their constant support. An enormous thank you to the chairs of the Tort session of the Common Core project, Mathias Reimann (until 2002) and Franz Werro (since 2003), and all participants to the annual meetings of the Tort sessions for their valuable comments and suggestions.

Our thanks to Carol Forrest for her help in editing this book. We would also like to thank Eric Engle for his collaboration in this project between 2002 and 2004. Last but not least, we are indebted to Carla Boninsegna for her precious help in organising our meetings, and 
Cambridge University Press

978-0-521-19491-4 - Personality Rights in European Tort Law

Edited by Gert Brüggemeier , Aurelia Colombi Ciacchi , Patrick O'Callaghan

Frontmatter

More Information

PREFACE

Xvii

to Jodie Barnes, Sinéad Moloney and Finola O’Sullivan at Cambridge University Press who so kindly helped to bring this project to a good end.

GERT BRÜGGEMEIER University of Bremen AURELIA COLOMBI CIACCHI University of Bremen PATRICK O'CALLAGHAN Newcastle University 
Cambridge University Press

978-0-521-19491-4 - Personality Rights in European Tort Law

Edited by Gert Brüggemeier , Aurelia Colombi Ciacchi , Patrick O'Callaghan

Frontmatter

More Information

\section{Editorial note}

Most of the following country reports were completed in 2007 but for reasons of the work schedule we were unable to make major updates to the reports before publication. Naturally, there have been developments since 2007, some of a relatively minor nature and some which are clearly quite significant. In England, while Campbell v. MGN remains the leading authority for the fledgling informational privacy tort, there have been some decisions of the lower courts, which should be mentioned here, namely McKennitt v. Ash, ${ }^{1}$ Murray v. Express Newspapers plc ${ }^{2}$ and Mosley v. News Group Newspapers Ltd. ${ }^{3}$ In Germany, as set out in Case 7, courts and scholars traditionally regarded pictures of public figures as pictures of contemporary history. ${ }^{4}$ But the German reporters inform us that the legal landscape has changed following the decision of the European Court of Human Rights in von Hannover. ${ }^{5}$ Courts in Germany now allow publication of pictures of public figures only when they are deemed newsworthy. The newsworthiness may be due to the fact that the person is depicted in an official function or if there is a story to the photo which is of public interest. ${ }^{6}$ The public interest may also follow from a text added to the photo. ${ }^{7}$

\footnotetext{
1 [2008] QB 73.

2 [2008] 3 WLR 1360.

3 [2008] EMLR 20.

4 Personen der Zeitgeschichte, see H. Neumann-Duesberg, 'Bildberichterstattung über absolute und relative Personen der Zeitgeschichte' (1960) JZ 114-18. Cf. KG Berlin ZUM-RD 2006, 552; LG Berlin ZUM-RD 2006, 571.

${ }^{5}$ ECHR decision of 24 June 2004 - 59320/00, GRUR 2004, 1051; (2005) 40 EHRR 1.

${ }^{6}$ BGHZ 171, 275; 158, 218, 222; NJW 2008, 3134; BVerfGE 101, 361, 389.

7 BGH NJW 2008, 3141.
} 
Cambridge University Press

978-0-521-19491-4 - Personality Rights in European Tort Law

Edited by Gert Brüggemeier , Aurelia Colombi Ciacchi , Patrick O'Callaghan

Frontmatter

More Information

But perhaps the most extensive changes have occurred in Ireland. Val Corbett, the Irish reporter, has kindly provided the following overview of these changes:

Since the time of writing, there have been significant developments in Irish defamation and privacy law which will alter the advice provided in many of the cases contained within the text.

First, the Defamation Bill was enacted in the form of the Defamation Act 2009 and took effect from 1 January 2010. The Act applies to all causes of action accruing before its commencement. ${ }^{8}$ Much of the reform introduced by the Act is procedural in effect. Many of its provisions have simply put the common rules relating to defamation on a statutory footing. For example, the common law of justification has been abolished and replaced with the similar defence of truth. ${ }^{9}$ Furthermore, the common law defences of absolute privilege, ${ }^{10}$ qualified privilege, ${ }^{11}$ consent $^{12}$ and offer to make amends ${ }^{13}$ are put on a statutory footing. The legislation alters the common law defence of 'fair comment' to a statutory one of 'honest opinion.' ${ }^{14}$ A new defence of 'innocent publication' has also been introduced. ${ }^{15}$ This defence will be welcomed by publishing houses (and possibly internet service providers) who - under the old regime - could be potentially liable for defamation even though they may have only innocently facilitated the publication of the defamatory material. Equally welcome is the provision which allows the defendant to give evidence in mitigation of damage where [s] he published (or offered to publish) an apology and crucially provides that any such apology is not admissible in any civil proceedings as evidence of liability in defamation proceedings. ${ }^{16}$

Much of the criticism of Irish defamation law derived from the fact that the tort was essentially one of strict liability, i.e. there was no defence if the defamatory statement was mistakenly - although not negligently or recklessly - published. The Act has introduced a new defence of 'fair and reasonable publication on a matter of public interest' to fill this lacuna. ${ }^{17}$ The stated purpose of this defence is to allow reasonable and fair publication of material which is considered to be in the 'public interest' even where it is capable of being defamatory. While it remains to be seen how this defence will be interpreted by the courts, there is concern that, as drafted, the defence is unduly

\footnotetext{
${ }^{8}$ Section 3 of the Defamation Act 2009.

9 Section 16 of the Defamation Act 2009.

10 Section 17 of the Defamation Act 2009.

11 Section 18 of the Defamation Act 2009.

${ }^{12}$ Section 25 of the Defamation Act 2009.

13 Section 22 of the Defamation Act 2009.

${ }^{14}$ Section 20 of the Defamation Act 2009.

15 Section 27 of the Defamation Act 2009.

${ }^{16}$ Section 24 of the Defamation Act 2009.

17 Section 26 of the Defamation Act 2009.
} 


\section{CAMBRIDGE}

Cambridge University Press

978-0-521-19491-4 - Personality Rights in European Tort Law

Edited by Gert Brüggemeier , Aurelia Colombi Ciacchi , Patrick O'Callaghan

Frontmatter

More Information

narrow and could be practically unworkable. Furthermore, the introduction of this defence could be seen as a retrograde step for proponents of freedom of expression as it expressly replaces ${ }^{18}$ innovative defences which have been developed by the Irish courts in recent years. ${ }^{19}$

The second development in Irish law is that breach of privacy claims as between private parties are now recognised under Irish law. While claims for breach of privacy by the State have long been recognised by the Irish courts, ${ }^{20}$ it was not until the recent High Court decision of Herrity v. Associated Newspapers (Ireland) Limited, ${ }^{21}$ that it was explicitly recognised that a cause of action for breach of privacy could exist between private parties.

Once again we would like to express our gratitude to the individual authors for all of their hard work and effort.

Gert Brüggemeier

Aurelia Colombi Ciacchi

Patrick O’Callaghan

January 2010

18 Section 15 of the Defamation Act 2009.

${ }_{19}$ In particular, the defence of public interest developed in Leech v. Independent Newspapers (Ireland) Ltd [2007] IEHC 223.

20 See McGhee v. Attorney General [1974] IR 384; Norris v. Attorney General [1984] IR 36; Kennedy v. Ireland [1987] 1 IR 587.

${ }^{21}$ [2008] IEHC 249. 
Cambridge University Press

978-0-521-19491-4 - Personality Rights in European Tort Law

Edited by Gert Brüggemeier , Aurelia Colombi Ciacchi , Patrick O'Callaghan

Frontmatter

More Information

\section{Abbreviations}

\section{General abbreviations}

$\S$

$\S \S$

Art.

CC

cf.

ch.

COM

EC

ECHR

ECJ

ECR

\section{ECtHR}

ed.

edn.

eds.

e.g.

EHRR

ERPL

et al.

et seq.

EU

EU Charter

ibid. paragraph

paragraphs

Article

Civil Code

confer

chapter

Document of the European Commission European Community

European Convention on Human Rights and Fundamental Freedoms

European Court of Justice

Reports of the Decisions of the European Court

European Court of Human Rights

editor

edition

editors

exempli gratia

European Human Rights Reports

European Review of Private Law

et alia

et sequitur

European Union

Charter of Fundamental Rights of the European Union

ibidem 
Cambridge University Press

978-0-521-19491-4 - Personality Rights in European Tort Law

Edited by Gert Brüggemeier , Aurelia Colombi Ciacchi , Patrick O'Callaghan

Frontmatter

More Information

$\begin{array}{ll}\text { xxii } & \text { LIST OF ABbREviations } \\ \text { ICCPR } & \begin{array}{l}\text { International Convenant on Civil and } \\ \text { Political Rights } \\ \text { ICESCR }\end{array} \\ \text { International Convenant on Economic, } \\ \text { i.e. } & \text { Social and Cultural Rights } \\ \text { p. } & \text { id est } \\ \text { PC } & \text { page } \\ \text { pp. } & \text { Penal Code } \\ \text { TEU } & \text { pages } \\ \text { UN } & \text { Treaty establishing European Union } \\ \text { v. } & \text { United Nations } \\ \text { Vol. } & \text { versus } \\ \text { Vols. } & \text { volume } \\ \end{array}$

\section{Abbreviations by Country}

Austria

$\begin{array}{ll}\text { ABGB } & \text { Allgemeines Bürgerliches Gesetzbuch } \\ \text { ASVG } & \begin{array}{l}\text { Allgemeines Sozialversicherungsgesetz } \\ \text { Beilage(n) zu den stenographischen } \\ \text { BlgNR }\end{array} \\ & \begin{array}{l}\text { Protokollen des Nationalrates } \\ \text { E-Commerce Gesetz }\end{array} \\ \text { ECG } & \text { Exekutionsordnung } \\ \text { EO } & \text { Evidenzblatt der } \\ \text { EvBL } & \text { Rechtsmittelentscheidungen des Obersten } \\ & \text { Gerichtshofs } \\ \text { MedienG } & \text { Mediengesetz } \\ \text { MR } & \text { Medien und Recht } \\ \text { OGH } & \text { Oberster Gerichtshof } \\ \text { ÖJZ } & \text { Österreichische Juristen-Zeitung } \\ \text { RV } & \text { Regierungsvorlage } \\ \text { StGB } & \text { Strafgesetzbuch } \\ \text { UrhG } & \text { Urheberrechtsgesetz } \\ \text { UWG } & \text { Gesetz gegen den unlauteren Wettbewerb }\end{array}$

Belgium

AJT

AM

Cass.

Algemeen Juridisch Tijdschrift

Auteurs et Média

Cour de cassation (belgique) 


C.civ.
JLMB
JT
Rec.Cass.
TBBR

England

AC

All ER

CA

$\mathrm{Ch}$

EMLR

EWHC

FSR

HL

HRA

$\mathrm{KB}$

LR

QB

TLR

WLR

Finland

FIM

France

Ann.prop.ind.

Ass. plén.

Bull. civ.

Bull. crim.

\section{Cass}

Cass. I civ.

Cass. II civ.

Cass. III civ.

Cass. comm.

Cass. crim

CC
Code civil

Jurisprudence de Liège, Mons et Bruxelles Journal des tribunaux

Recente Arresten van het Hof van Cassatie Tijdschrift voor Belgisch Burgerlijk Recht

Law Reports, Appeal Cases

All England Law Reports

Court of Appeal

Law Reports, Chancery Division

Entertainment \& Media Law Reports

England and Wales High Court

Fleet Street Reports

House of Lords

Human Rights Act

Law Reports, King's Bench

Law Reports

Law Reports, Queen's Bench

Times Law Reports

Weekly Law Reports

Finnish Markka

Annales de la propriété industrielle, artistique et littéraire

Assemblée plénaire

Bulletin des arrêts de la Cour de cassation (chambres civiles)

Bulletin des arrêts de la Cour de cassation (chambre criminelle)

Cour de cassation

Cour de cassation (1ère chambre civile)

Cour de cassation (2ème chambre civile)

Cour de cassation (3ème chambre civil)

Cour de cassation, chambre commerciale

Cour de cassation, chambre criminelle

Conseil constitutionnel 
Cambridge University Press

978-0-521-19491-4 - Personality Rights in European Tort Law

Edited by Gert Brüggemeier , Aurelia Colombi Ciacchi , Patrick O'Callaghan

Frontmatter

More Information

$\begin{array}{ll}\text { xxiv } & \text { List OF AbBREViations } \\ \text { C. civ. } & \text { Code civil } \\ \text { CE } & \text { Conseil d'Etat } \\ \text { chr. } & \text { chronique } \\ \text { D } & \text { Dalloz } \\ \text { DC } & \text { Décision du Conseil constitutionnel } \\ \text { Décl./DDHC } & \text { Déclaration des droits de l'homme et du } \\ & \text { citoyen } \\ \text { DP } & \text { Dalloz Périodique } \\ \text { Gaz. Pal. } & \text { Gazette du Palais } \\ \text { IR } & \text { Informations rapides } \\ \text { JCP } & \text { JurisClasseur Périodique (Semaine } \\ & \text { juridique) } \\ \text { RDP } & \text { Revue du droit public et de la science poli- } \\ & \text { tique en France et à l'étranger } \\ \text { rec. } & \text { Recueil } \\ \text { Rev. Trim. Droit Civ. } & \text { Revue trimestrielle du droit civil } \\ \text { somm. } & \text { Sommaire(s) } \\ \text { TGI } & \text { Tribunal de grande instance } \\ \text { Trib. civ. } & \text { Tribunal civil }\end{array}$

Germany

AG

ArbG

BAG

BGB

$\mathrm{BGH}$

BGHZ

BVerfG

BVerfGE

EuGRZ

GG

GRUR

$\mathrm{JZ}$

KUG

LG

NJW
Amtsgericht

Arbeitsgericht

Bundesarbeitsgericht

Bürgerliches Gesetzbuch

Bundesgerichtshof

Entscheidungen des Bundesgerichtshofs in

Zivilsachen

Bundesverfassungsgericht

Entscheidungen des

Bundesverfassungsgerichts

Europäische Grundrechte-Zeitschrift

Grundgesetz

Gewerblicher Rechtsschutz und

Urheberrecht

Juristen-Zeitung

Kunsturhebergesetz

Landgericht

Neue Juristische Wochenschrift 
Cambridge University Press

978-0-521-19491-4 - Personality Rights in European Tort Law

Edited by Gert Brüggemeier , Aurelia Colombi Ciacchi , Patrick O'Callaghan

Frontmatter

More Information

\section{NJW-RR}

OLG

RG

RGBl.

RGZ

StGB

Greece

Ireland

IEHC

IR

Italy

App.

Arch. civ.

Cass.

Cass. pen.

CC

Corriere giur.

Corte cost.

Cost.

CP

Danno e resp.

Dir. Aut.

Foro it.

Giur. cost.

Giur. it.

Giust. civ.

Nuova giur. civ. comm.

Rass. dir. civ.

Resp. civ.

Riv. crit. dir. priv.

Riv. dir. civ.

Riv. trim. dir. proc. civ.
Neue Juristische

Wochenschrift - Rechtsprechungsreport

Oberlandesgericht

Reichsgericht

Reichsgesetzblatt

Entscheidungen des Reichsgerichts in

Zivilsachen

Strafgesetzbuch

The High Court of Ireland Decisions

Irish Reports

Corte d'appello

Archivio civile

Corte di Cassazione

Cassazione penale

Codice civile

Corriere giuridico

Corte costituzionale

Costituzione della Repubblica Italiana

Codice penale

Danno e responsabilità

Diritto d'autore

Foro italiano

Giurisprudenza costituzionale

Giurisprudenza italiana

Giustizia civile

Nuova giurisprudenza civile commentata

Rassegna di diritto civile

Responsabilità civile e previdenza

Rivista critica del diritto privato

Rivista di diritto civile

Rivista trimestrale di diritto e procedura civile 
Cambridge University Press

978-0-521-19491-4 - Personality Rights in European Tort Law

Edited by Gert Brüggemeier , Aurelia Colombi Ciacchi , Patrick O'Callaghan

Frontmatter

More Information

xxvi

LIST OF ABBREVIATIONS

The Netherlands

BW

HR

Burgerlijk Wetboek

$\mathrm{NJ}$

Hoge Raad

NJB

Nederlandse Jurisprudentie

NJV

Nederlands Juristenblad

Nederlandse Juristenvereniging

\section{Portugal}

Ac. STJ

Ac. TC.

BMJ

$\mathrm{CC}$

$\mathrm{CP}$

CPC

CPP

Cpub

CRP

EJ

LI

STJ

Acórdão do Supremo Tribunal de Justiça Acórdão do Tribunal Constitucional

Boletim do Ministério da Justiça

Código Civil

Código Penal

Código de Processo Civil

Código de Processo Penal

Código da Publicidade

Constituição da República Portuguesa

Estatuto do Journalista

Lei de Imprensa

Supremo Tribunal de Justiça

Scotland

SC

Session Cases

SLT

Scottish Law Times

Spain

ADC

CC

CE

LO

RTC

STC

STS

STSJ

TC

Anuario de Derecho Civil

Código civil

Constitución Española

Ley Orgánica

Repertorio del Tribunal Constitucional

Sentencia del Tribunal Constitucional

Sentencia del Tribunal Supremo

Sentencia del Tribunal Superior de Justiça

Tribunal Constitucional

Switzerland

ATF/BGE

Arrêts du tribunal fédéral/Entscheidungen des Bundesgerichts 


CC/ZGB
CO/OR
JAAC
JdT
JTPI
RS/SR

RVJ
SJ
SJZ
TF/BG

USA

A./Atl. (2d)

Ala.

Amends.

App.

Cal.

cert. den.

Cir.

Const.

D.

D.C.

F.

Ga.

Kan.

Ky.

La.

Md.

Mich.

Minn.

Mo.

N.C.

N.E.

N.H.

N.W.

N.Y.
Code Civil/Zivilgesetzbuch

Code des Obligations/Obligationenrecht Jurisprudence des autorités administratives de la conféderation Journal des tribunaux Journal des tribunaux de première instance

Recueil systématique du droit fédéral/ Systematische Sammlung des Bundesrechts

Revue valaisanne de jurisprudence Semaine judiciaire Schweizerische Juristen-Zeitung Tribunal fédéral/Bundesgericht

Atlantic Reporter (Second Series)

Alabama Reports

Amendments

Appellate Reports

California Reports

certiorari denied

Circuit (Federal Courts of Appeal)

Constitution

District (Federal Courts)

District of Columbia

Federal Reporter

Georgia Reports

Kansas Reports

Kentucky Reports

Louisiana Reports

Maryland Reports

Michigan Reports

Minnesota Reports

Missouri Reports

North Carolina Reports

North Eastern Reporter

New Hampshire Reports

North Western Reporter

New York Reports 


\section{CAMBRIDGE}

Cambridge University Press

978-0-521-19491-4 - Personality Rights in European Tort Law

Edited by Gert Brüggemeier , Aurelia Colombi Ciacchi , Patrick O'Callaghan

Frontmatter

More Information

XXViii LIST OF ABBREVIATIONS

N.Y.S.

N.Y. Sess.

N.Y. Sup. Ct.

P./Pac.

R.I.

S.Ct.

S.E.

So.

S.W.

Tex.

U.S.

Wis.
New York Supplement

New York Session Laws

New York Supreme Court of Judicature

(State Court of First Instance (1848-date)

Pacific Reporter

Rhode Island Reports

U.S. Supreme Court Reports

South Eastern Reporter

Southern Reporter

South Western Reporter

Texas Reports

U.S. Supreme Court Reports

Wisconsin Reports 